\title{
Correction to: How to squat? Effects of various stance widths, foot placement angles and level of experience on knee, hip and trunk motion and loading
}

Silvio Lorenzetti ${ }^{1,2^{*}}$, Mira Ostermann ${ }^{1,3}$, Fabian Zeidler ${ }^{1,4}$, Pia Zimmer ${ }^{1,4}$, Lina Jentsch ${ }^{1}$, Renate List ${ }^{1}$, William R. Taylor ${ }^{1}$ and Florian Schellenberg ${ }^{1}$

\section{Correction to: BMC Sports Sci Med Rehabil (2018) 10:14 https://doi.org/10.1186/s13102-018-0103-7}

Following publication of the original article [1], the authors reported an error in the following sentence on page 8: "In general, knee varus (negative $\Delta D^{*}$ ) is a much more common deficit than valgus, and a more negative $\Delta \mathrm{D}^{*}$ value in the novice squatters compared to the experienced ones was therefore expected."

The correct sentence reads as follows: "In general, knee varus (positive $\Delta \mathrm{D}^{*}$ ) is a much more common deficit than valgus, and a more positive $\Delta \mathrm{D}^{*}$ value in the novice squatters compared to the experienced ones was therefore expected."

Thanks to Moshe Marko for noticing this error.

\section{Author details}

'Institute for Biomechanics, ETH Zurich, Leopold-Ruzicka-Weg 4, 8093 Zürich, Switzerland. ${ }^{2}$ Swiss Federal Institute of Sport Magglingen, SFISM,

Hauptstrasse 247, 2532 Magglingen, Switzerland. ${ }^{3}$ Department of Business, Health \& Social Work, Bern University of Applied Science, Schwarztorstrasse 48, 3007 Bern, Switzerland. ${ }^{4}$ Department of Medicine, Sports \& Healthcare, University of Applied Science Technikum Vienna, Höchstädtplatz 6, 1200 Wien, Austria.

Published online: 29 January 2020

\section{Reference}

1. Lorenzetti S, Ostermann M, Zeidler F, et al. How to squat? Effects of various stance widths, foot placement angles and level of experience on knee, hip and trunk motion and loading. BMC Sports Sci Med Rehabil. 2018;10:14 https://doi.org/10.1186/s13102-018-0103-7.

The original article can be found online at https://doi.org/10.1186/s13102018-0103-7

* Correspondence: sl@ethz.ch

'Institute for Biomechanics, ETH Zurich, Leopold-Ruzicka-Weg 4, 8093 Zürich, Switzerland

${ }^{2}$ Swiss Federal Institute of Sport Magglingen, SFISM, Hauptstrasse 247, 2532

Magglingen, Switzerland

Full list of author information is available at the end of the article

(c) The Author(s). 2020 Open Access This article is distributed under the terms of the Creative Commons Attribution 4.0 International License (http://creativecommons.org/licenses/by/4.0/), which permits unrestricted use, distribution, and reproduction in any medium, provided you give appropriate credit to the original author(s) and the source, provide a link to the Creative Commons license, and indicate if changes were made. The Creative Commons Public Domain Dedication waiver (http://creativecommons.org/publicdomain/zero/1.0/) applies to the data made available in this article, unless otherwise stated. 